DIGITAL COMMONS
$@$ UNIVERSITY OF SOUTH FLORIDA

Volume 11

Issue 1 Summer 2021

\section{ABO: Interactive Journal for Women in the Arts, 1640-1830}

\title{
Looking Beyond the Enlightenment Mother-Teacher: Anna Letitia Barbauld and the Eighteenth-Century Maternal Ideal
}

\author{
Kathryn J. Ready \\ The University of Winnipeg, k.ready@uwinnipeg.ca
}

Follow this and additional works at: https://digitalcommons.usf.edu/abo

Part of the Dramatic Literature, Criticism and Theory Commons, Educational Methods Commons, Feminist, Gender, and Sexuality Studies Commons, and the Literature in English, British Isles Commons

\section{Recommended Citation}

Ready, Kathryn J. (2021) "Looking Beyond the Enlightenment Mother-Teacher: Anna Letitia Barbauld and the Eighteenth-Century Maternal Ideal," ABO: Interactive Journal for Women in the Arts, 1640-1830: Vol.11: Iss.1, Article 3.

http://doi.org/10.5038/2157-7129.11.1.1262

Available at: https://digitalcommons.usf.edu/abo/vol11/iss1/3

This Scholarship is brought to you for free and open access by Digital Commons @ University of South Florida. It has been accepted for inclusion in ABO: Interactive Journal for Women in the Arts, 1640-1830 by an authorized administrator of Digital Commons @ University of South Florida. For more information, please contact digitalcommons@usf.edu. 


\title{
Looking Beyond the Enlightenment Mother-Teacher: Anna Letitia Barbauld and the Eighteenth-Century Maternal Ideal
}

\begin{abstract}
Based on her popular prose writing for children, liberal Dissenter Anna Letitia Barbauld has been cited as a prominent example of the Enlightenment mother-teacher associated with the influence of John Locke and Jean-Jacques Rousseau. However, close reading of her poetry reveals a complex maternal ideal in operation that was in part that of the Enlightenment mother-teacher, in part a modified form of republican motherhood, a strategic composite drawn, on the one hand, from classical republican discourse, which promoted the woman's role in fostering patriotism and liberty, and, on the other, from contemporary defences of commerce, which highlighted women's civilizing and humanizing roles. Barbauld's poetic career is compelling in illuminating not only the complexity of the eighteenth-century maternal ideal but also its simultaneous opportunities and limitations for women. While the eighteenth-century maternal ideal allowed the possibility for exciting innovation and reinterpretation of traditional gender categories, expanding the boundaries of feminine authority and authorship, it could equally be exploited by those bent upon undermining women's efforts to enlarge their social and cultural sphere of action.
\end{abstract}

\section{Keywords}

Barbauld; Dissent; Enlightenment mother-teacher; republican motherhood; commerce

\section{Creative Commons License}

(c) (1) (\$)

This work is licensed under a Creative Commons Attribution-Noncommercial 4.0 License 
For a long time disregarded or dismissed, the contribution of women to the field of eighteenth-century education and the emergent market for children's literature has now been widely recognized. As part of this revisionist project, scholars have given quite a bit of thought already to the associated character of the Enlightenment mother-teacher. ${ }^{1}$ The prominence that the mother-teacher attained as a character during the eighteenth century has been connected with the growth of a wealthy commercial middle class and the influence of such Enlightenment thinkers as John Locke and Jean-Jacques Rousseau. An oft-cited example of the Enlightenment mother-teacher is the famous liberal Dissenting writer Anna Letitia or Lætitia Barbauld (née Aikin, 1743-1825). Yet those interested in Barbauld's activities as mother-teacher have tended to focus on her prose writing for children. This focus has encouraged assumptions that in her maternal ideal she was taking primary cues from Locke and Rousseau. If we look at her poetry, we see that the maternal ideal Barbauld drew upon to license herself as a poet, including as a political poet, actually brought together multiple influences. It was in part that of the Enlightenment mother-teacher, with Barbauld looking more clearly to Locke than to Rousseau. However, it was in equal part a modified form of republican motherhood, a strategic composite drawn on the one hand, from classical republican discourse, which promoted the woman's role in fostering patriotism and liberty, and, on the other, from contemporary defences of commerce, which highlighted women's civilizing and humanizing roles. Barbauld's poetic career is compelling in illuminating not only the complexity of the eighteenth-century maternal ideal but also its simultaneous opportunities and limitations for women. While the eighteenth-century maternal ideal allowed the possibility for exciting innovation and reinterpretation of traditional gender categories, expanding the boundaries of feminine authority and authorship, it could equally be exploited by those bent upon undermining women's efforts to enlarge their social and cultural sphere of action.

Barbauld first achieved celebrity as a children's writer with the publication of her Lessons for Children, from Two to Three Years Old (1778), which, she explains to readers in the preface, was directly inspired by her experience as the mother and teacher of "a particular child" (2). She and her husband had adopted her nephew Charles Aikin in 1775, a year after establishing a boys' school at Palgrave, Suffolk, where she "taught ... reading and religion to the youngest pupils" and "geography and history, English composition and oratory, and natural science" to some of the older boys (McCarthy, "The Celebrated Academy at Palgrave" 298). She went on to produce Lessons for Children, of Three Years Old (Part I: 1778,

1. For more general background on the Enlightenment mother-teacher, see Myers, "Impeccable Governesses." 
Part II: 1779); Lessons for Children, from Three to Four Years Old (1779); Hymns in Prose for Children (1781); Evenings at Home (1792-96), co-written with her brother John; The Female Speaker (1811); and a number of pieces posthumously collected in A Legacy for Young Ladies (1826). ${ }^{2}$ Barbauld's later prose writings for children complement the earlier by aiming at progressively older juvenile audiences, and the increased material directed at young female readers reflects her experience at Hampstead and Stoke Newington as a private tutor for girls.

Much of Barbauld's best-known children's writing enacts the role of Enlightenment mother-teacher, beginning with the Mamma of the Lessons. Many of her later prose pieces for children are written either as epistolary addresses to young women or as dialogues between mother and daughter. While the speaker of the Hymns never assumes an explicitly maternal aspect, in Hymn III she glorifies the mother who "feedeth . . . [her child's] mind with knowledge" (241). ${ }^{3}$ Critics have already identified the Mamma of the Lessons as directly influenced by Locke and Rousseau, with some questioning the extent of Barbauld's debt to Rousseau, arguing that he essentially restricts maternal prerogatives to children's bodily needs. ${ }^{4}$ Building on the connection to Locke, Joanna Wharton has examined the Lessons and Hymns in terms of how "Barbauld interpreted and implemented Lockean and Hartleyan theories of mental development in her use of sensible images."

A Lockean influence is discernible in "On Female Studies" (1826), where Barbauld cites the role of the mother-teacher as part of her proposed plan for female education. She begins by claiming for "[e]very woman . . . the general character of a rational being, as well as the more confined one belonging to the female sex" (475). In her view, while a woman "is excused from all professional knowledge" (475-76), she otherwise has the same goals of mental improvement, and, as a mother, must have sufficient knowledge to "share . . . in the education of ... children" (476) and to determine "with whom to confide [that] education ...

\footnotetext{
2. Barbauld's contributions to Evenings are listed in Lucy Aikin edition of Works (1: xxxvixxxvii), but scholars have since questioned the reliability of these attributions and some prefer to treat all the pieces as collaborative. See, for example, Levy, Family 25-26.

3. Anna Letitia Barbauld, Selected Poetry and Prose. Unless otherwise indicated, this edition is my source text for all quotations from Barbauld's prose. Citations are indicated in the text parenthetically.

4. Relevant secondary sources include Pickering, Darton, Goldstone, Robbins, "Lessons for Children and Teaching Mothers," Hilton, and McCarthy, Voice 198.

5. Wharton 107. Evidently, Barbauld's friend Joseph Priestley, a one-time colleague of her father's at the liberal Dissenting academy at Warrington, did much to popularize David Hartley's philosophy.
} 
and how to judge ... [children's] progress and the methods used to improve them" $(481){ }^{6}$

While largely overlooked in scholarly discussions of Barbauld's prose writings for children, her poetry features many poetic celebrations of mothers, including as mother-teachers.7 “On Mrs. P[riestley]'s Leaving Warrington” (1767; 1994) offers a paean to Amanda (Mary Priestley, née Wilkinson) as mother-teacher in the lines "While lisping tongues thy precepts shall repeat, / And little hearts with growing fondness beat" (93-94). "A Summer Evening's Meditation" (n.d.; 1773) and "Address to the Deity" $(1767 ; 1773)$ arguably both envision God in the capacity of mother-teacher. In the first, the poet returns from an imagined voyage to "embryo systems and unkindled suns" that "[s]leep in the womb of chaos" (9697), to seek comfort with a Deity whose "gentler voice . . . . . . whispers comfort to the swelling heart" (109-10). In the second, she swears obeisance to a Deity whose "precepts guide" her and in whose "arms" she hopes one day to "rest, unmov'd by all alarms" (69). ${ }^{9}$

From the very beginning, Barbauld's poetry shows her looking not only to the figure of the Muse but also to that of the Enlightenment mother-teacher in order to sanction her poetic activity. Barbauld appeals to her friendship with Amanda to justify the composition of "On Mrs. P[riestley]," signalling her own desire to act as mother-teacher in the mentorly interest she has taken in her friend's young daughter, although she voices a Lockean sounding fear that "[e]ach soft impression" (110) she has made on the girl's mind will be effaced when the Priestleys move away. In "To Mrs. P[riestley], with some Drawings of Birds and Insects" (1767?; 1773), she rejoices that she now writes at Amanda's express "command," this confidence wavering somewhat in "The Invitation: To Miss B *****" (1762? or post-1766?; 1773), which concludes with the poet renouncing "arduous themes" (183) and concealing "her head in the green lap of spring" (188), exposing continuing fear of censure and hope of reconciling poetic

\footnotetext{
6. I have elsewhere discussed at some length the Enlightenment feminist implications of Locke's writings; see Ready.

7. See McCarthy, Voice 199; Robbins, "Re-making Barbauld's Primers" 158; McGillis 163; and Myers, "Of Mice and Mothers" 259.

8. My source for Barbauld's poetry is Poems of Anna Letitia Barbauld, edited by William McCarthy and Elizabeth Kraft. I give both dates of composition and first publication parenthetically, with speculative composition dates followed by a question mark.

9. In her analysis of the Hymns, Vallone emphasizes Barbauld's vision of God as father and sovereign (78). Yet Hymn V includes a passage comparing God to "the mother [who] moveth about the house with her finger on her lips, and stilleth every little noise that her infant be not disturbed" (Barbauld, Selected Poetry and Prose 244), and Vallone herself notes that in the Hymns "children enjoy the sight of lambs frolicking with their mothers" (79).
} 
ambition with feminine propriety, under the implied tutelage of some maternal figure (equally a possible subtext of "Summer Evening's Meditation").

Barbauld appears as mother-teacher most obviously in her poems addressed to children, including "Verses written in the Leaves of an ivory Pocket-Book, presented to Master T[urner]" $(1769 ; 1825)$ and "Lines written in a young Lady's Album of different-coloured Paper" (n.d.; 1825), and her poems to be recited by a particular child and/or for a child audience, such as "Petition of a Schoolboy to his Father" (n.d.; 1826) and "Lines to be spoken by Thomas Denman, on the Christmas before his Birthday, when he was four Years old" (1782; 1994). Both "Verses in an ivory Pocket-book" and "Lines in a young Lady's Album" plainly evoke the Lockean idea of the mind as tabula rasa.

To a lesser but still striking extent, we can see Barbauld adopting the persona of the Enlightenment mother-teacher in a series of poems "address[ed] to younger men-younger in wisdom and, progressively, also in years - correcting, chiding, or even rebuking their errors," beginning with "To the Baron de Stonne, who had wished at the next Transit of Mercury to find himself again between Mrs. La Borde and Mrs. B[arbauld]" (1786; 1825) and continuing with Epistle to William Wilberforce, Esq. on the Rejection of the Bill for abolishing the Slave Trade (1791; 1791), "[Lines to Samuel Rogers in Wales on the Eve of Bastille Day, 1791]” (1791; 1994), “To Mr. S. T. Coleridge” (1797; 1799), and "To Lord Byron" (post-1815; 1994). ${ }^{10}$

To some extent, the marked presence of the Enlightenment mother-teacher in Barbauld's poetry appears at odds with the separation that she sought initially to draw between poetry and children's writing. In the preface to the Hymns, Barbauld characterizes poetry for children as "a condescension of . . . [the] Muse" and questions "whether poetry ought to be lowered to the capacities of children" (237), suggesting doubts about the reconcilability of her burgeoning career as a children's writer with her already established career as a poet. As McCarthy underscores, the preface to the first volume of Lessons (a text published anonymously without a demand for copyright) "sounds an aggressively defensive note" regarding the value of children's writing (Voice 191). Yet with the popular success of her prose writing for children Barbauld seems to have become increasingly interested in reconciling her two careers. Those who later anthologized Barbauld's poetry evidently responded to the image she had established for herself as Enlightenment mother-teacher through the Lessons and the Hymns. Some poems originally intended for adult readers, for example, "A

10. McCarthy, Voice 254. 
Mouse's Petition" (1767; 1773), found their way into collections intended for child readers or as elocutionary aids for adolescents.

At the same time, a close look at the maternal ideal being put forward in Barbauld's poetry reveals it to be multifaceted. There are hints of the classical republican mother in the description of Amanda as "[a] soul refined, exalted far beyond / The common level of a blameless mind" (27-28), marked by "steady patience, and calm fortitude" (30). Barbauld directly compares the female subject of another early poem: "[A Character of Sarah Hallowell Vaughan]" (1770; 1825) to "the dames of old heroic days" (1), "[t]he mighty mothers of immortal Rome" (4), in bidding "lovers, brothers, sons aspire to fame" (12) and in cherishing virtue "[i]n the young bosom," inspiring "many a godlike deed" (13-14).

Mark Philp notes that within "eighteenth-century political thought and practice" there persisted "an understanding of the nature of politics that drew heavily on ancient and classical sources ... whose influence ... [had been] revivified and concentrated by the writings of [Niccolò] Machiavelli and [James] Harrington" $(459,460)$. Against the "[a]nti-monarchical republicanism" that existed "on the borders of political controversy throughout the eighteenth century," this classically inspired eighteenth-century republicanism regarded mixed government as the best form of rule (Philp 458). ${ }^{11}$ In The Spirit of the Constitution (1790), John Aikin explicitly endorses a government that combines the strengths of monarchy, aristocracy, and democracy over "pure monarchy" (8). Another characteristic feature of classically inspired eighteenth-century republicanism was the equation of patriotism with liberty and the subordination of private to public interests. As Philip Hicks notes, while many eighteenth-century republicans continued to regard politics as "inherently masculine" and denounced "[w]omen in high places . . . as agents of "petticoat politics," they simultaneously celebrated the patriotism of heroines from ancient, medieval, and early modern European history; as such, "the republican inheritance . . . in some of its manifestations . . . offered a refuge, ironically, to the same politically engaged women" $(36,37)$. During the eighteenth century, among the most frequently cited examples of female patriotism from the ancient world was that of the Roman matron. Hicks specifically mentions Barbauld's "[Sarah Hallowell Vaughan]" among the noteworthy eighteenth-century literary celebrations of the Roman matron.

If we apply this knowledge of classical republicanism to a survey of Barbauld's poetic corpus as a whole, we find her drawing recurring inspiration from what has

11. For more on the history of the term republican, see Wootton 272. Hicks acknowledges that during the seventeenth and eighteenth centuries "scarcely any Britons identified themselves as 'republicans,' though they might apply the term pejoratively to others" (37). 
been called "classical republican motherhood." The Muse of "Corsica" (1768-69; 1773) acts as spokesperson for "the mountain goddess" (75) Liberty, who claims the Corsicans as "[h]er genuine sons, / A broken remnant, from the generous stock / Of ancient Greece, from Sparta's sad remains" (85-87). ${ }^{12}$ In To Wilberforce, the poet aligns herself with "Freedom's eager sons" (13) against the supporters of the slave trade and slavery. In the lines written for Samuel Rogers on the anniversary of Bastille Day, the poet bids the Muse "[c]hide the youth who holds his stay, / Far from Freedom's band away" (3-4), and in "To Coleridge," the poet takes the opportunity to exhort her addressee to "[a]ctive scenes" (38) and "fair exertion . . . / . . for country" (40-41). ${ }^{13}$ The image of French youth hearkening to the sound of the tocsin in "To a Great Nation" $(1792 ? ; 1793)$ at once echoes line 10 of "[To Samuel Rogers]" and indirectly recalls the various efforts of revolutionary Frenchwomen to emulate ancient republican heroines. ${ }^{14}$ The poet at least briefly assumes the aspect of a Roman matron in Eighteen Hundred and Eleven $(1811 ; 1812)$, where she praises the example of poet William Roscoe, "to whose patriot breast belong" (147), she tells us, "[t]he Roman virtue and the Tuscan song" (148).

Yet Barbauld's appropriation of classical republicanism is far from straightforward. As Harriet Guest, for one, appreciates, in "[Sarah Hallowell Vaughan]," "Barbauld explicitly distances herself from the model of republican motherhood" (251), celebrating "the "mighty mothers of immortal Rome' for their domestic virtues," and she offsets "the unambiguous classical republicanism of her poem on Corsica" with "poems ... prais[ing] a characteristically 'soft' and domestic femininity" (228). Guest could very well be thinking here of "On Mrs. $\mathrm{P}$ [riestley]." The poet's opening appeal to Amanda to relieve her "bleeding heart" (6) speaks to a familiar eighteenth-century association of women with sympathy. Equally modern sounding is the tribute to Amanda as a domestic salonnière, the poet nostalgically recalling the many days she spent at the Priestleys, where her friend oversaw a "social circle" that encouraged the "pleasing fires of lively

\footnotetext{
12. While identifying Liberty in "Corsica" with the tradition of warrior maiden, McCarthy notes the maternal aspect of Virtue in the same poem, punningly reflecting that " $t]$ his maternal idea will prove pregnant with possibilities" (Voice 58,103).

13. Many critics have overlooked the republicanism of this poem, Cox insisting that in "adopting this quasi-maternal role, Barbauld forgoes her claim to equality with or equivalence to the poet whom she addresses" (36). Somewhat differently, Coleman apprehends a "superiority implied" in Barbauld's assumption of parental authority over Coleridge although she considers the "poem ... a substantial tribute to Coleridge" (152). McCarthy is one of the few to identify a republican subtext, conjecturing, "Perhaps ... [Barbauld] saw ... [Coleridge] as a citizen-patriot, a future leader of reform" (Voice 402).

14. See Hicks 65.
} 
fancy" (47), banishing all "cold reserve, suspicion, sullen care" (45) and "dark unfriendly passions" (46). ${ }^{15}$

In this way, "On Mrs. P[riestley]" suggests the influence of another important line of thought that helped to shape eighteenth-century views about the social role of mothers (and of women in general). This particular line of thought was closely connected with contemporary defences of commerce. By the beginning of the eighteenth century, there was a common appreciation of the benefits of commerce (historically viewed with hostility by classical republicans), although many still worried about the luxury that came with commerce and the role of women in fostering luxury, threatening the independence of the male citizen-patriot. Some continued to uphold the ancient republics and classical republican motherhood unequivocally as ideals. ${ }^{16}$ However, during the same period emerged new champions of commerce, who celebrated its effects in civilizing society and women's participation in and contribution towards this process. David Hume writes that in modern, urbanized, commercial society,

[b]oth sexes meet in an easy and sociable manner; and the tempers of men, as well as their behaviour, refine apace. So that, beside the improvements ... from knowledge and the liberal arts . . . they must feel an encrease [sic] of humanity from the very habit of conversing together. $(271)^{17}$

Henry Home, Lord Kames picks up the Humean argument, taking satisfaction that "the gentle and insinuating manners of the female sex, tend to soften the roughness of the other sex" (169). John Bowles goes even further in his tribute to women who "soften" and "polish the rougher sex," claiming that "without their mild and genial influence, [men] would never exhibit any thing better than a race of barbarians" (18). He specifically highlights women's role in civilizing society through the cultivation of "tender sympathies" (18).

We can see hints of the Humean argument elsewhere in Barbauld's correspondence. Writing to her brother in 1774, Barbauld foregrounds women's civilizing role in teasing him that men "are hardly social creatures till . . . humanized and subdued by that passion which alone can tame ... [them] to 'all the soft civilities of life"": love, which makes "haughty, independent man . . . sensible to all the delicacies of sentiment, and softens his voice and address to the

15. For more on the domestic salon culture at Warrington, see MacLachlan 85.

16. See, for example, Stuart 16, 19.

17. "Of Refinement in the Arts" was originally published as "Of Luxury" in 1742. 
tone of les manières douces."18 Of course, as a Dissenter, Barbauld would have had a special investment in contemporary defenses of commerce. As she acknowledges in An Address to the Opposers of the Repeal of the Corporation and Test Acts (1790), Dissenters were widely recognized as "a mercantile people" (270) who had done much towards the development of the modern commercial capitalist economy. ${ }^{19}$

Thus, Barbauld's maternal ideal emerges as a combination of three distinct feminine ideals: (1) the Enlightenment mother-teacher, (2) the classical republican mother, and (3) the civilizing agent of modern commercial society. In bringing together the last two, Barbauld diverged from many Enlightenment thinkers who regarded them as mutually exclusive. Guest reports the opinion of William Alexander and James Fordyce, who saw "classical patriotism ... . [as] an inappropriate model for modern women to emulate because it is incompatible with feminine sensibility and humanity" (245).

Perhaps the most substantial literary evidence of Barbauld's divergence from thinkers such as Alexander and Fordyce is to be found in Eighteen Hundred and Eleven. Here, the poet initially seems to reject the example of classical republican motherhood in her lament for the widowed matron, whose sons have been killed in battle and whose daughters have been left widowed or forced to remain single because so few eligible bachelors have survived the carnage. However, as we know, her sorrow on behalf of the widowed matron does not prevent her from expressing maternal pride in Roscoe's "Roman virtue." Toward the end of the poem, the poet develops a telling contrast between the days when "Bonduca whirled the scythed car, / And the fierce matrons raised the shriek of war" (28990) and her own age, when "[1]ight forms beneath transparent muslins float, / And tutored voices swell the artful note" (291-92). Any impression readers might have from the terms of description that preference is being given to the women of Barbauld's own age necessarily fades when the poet makes the following observation:

But fairest flowers expand but to decay;

The worm is in thy core, thy glories pass away;

Arts, arms and wealth destroy the fruits they bring;

Commerce, like beauty, knows no second spring. (313-16)

\footnotetext{
18. Qtd. in the Lucy Aikin edition of Works, 2: 4.

19. Elsewhere, her brother claims that " $[\mathrm{t}]$ here is not a commercial town in England in which ... [Dissenters] do not form a large proportion of the most respectable and opulent inhabitants" (John Aikin, Address 25).
} 
The poet thus registers a simultaneous loss and gain for women over the course of history, speaking directly to the tension in Enlightenment historiography between virtue (synonymous in classical republican discourse with liberty and patriotism) and commerce, a tension discussed at length by J. G. A. Pocock among others. In the end, Barbauld seems to issue an unspoken call to female readers to aspire toward some kind of middle ground between the "fierce matrons" and the typical women of contemporary commercial society, preoccupied with fashion and ornamental accomplishments. $^{20}$

A number of other poems explore the ways in which modern women might promote liberty alongside sympathy and refinement. It is arguably this project that drives To Wilberforce. In lines 39 to 40, "Misery's pangs give birth / To jests unseemly, and to horrid mirth," the poet employs pointedly maternal imagery to underscore her disgust with the male members of parliament who reportedly laughed when abolitionists recounted stories of the horrific treatment of slaves. These lines serve tacitly to remind readers of the civilizing role eighteenthcentury mothers might hope to play through the cultivation of sympathy. Admittedly, the same poem includes two troubling female figures: "injur'd Afric" (45), who "[d]arts her own serpents at her Tyrant's breast" (46), and the planter's wife, a "Pale Beauty" (57) who combines "the Scythian, and the Sybarite" (62). As Kate Davies points out, the description of "injur'd Afric" calls to mind that famous "fulsome temptress" and "exotic seductress" Cleopatra. Davies concludes that " $[\mathrm{t}]$ he anti-commercial discourse ... [Barbauld] deploys requires that femininity fulfil no reparative function ... that it . . . be the incubus in the commercial machine" and "the diseased root of the problem of the slave trade itself" (148). Yet perhaps the message for contemporary female readers is not quite so bleak. While accepting that slavery corrupts those who are directly implicated in it, including its unhappy female victims, Barbauld leaves open the possibility that, as abolitionists, women might potentially have some effect in restoring virtue to commercial society. Indeed, there is some satisfaction offered

\footnotetext{
20. Clery, too, attempts to connect "Corsica," To Wilberforce, and Eighteen Hundred and Eleven to ancient thought, reading them as part of Barbauld's "innovative development of a "political Stoicism"" with roots in "a classical philosophy which, uniquely, did not differentiate between men and women when it came to the capacity for heroic action" $(193,188)$. In offering this reading, Clery seems to accept the distinction that many scholars have made between Stoicism and classical republicanism; at the same time, she challenges a view of Stoicism as necessarily encouraging submission to political authority (182). Yet she herself claims James Thomson, one of Barbauld's favourite poets, as a Stoic even as she acknowledges that he "has been associated with the ideas of classical republicanism or Neo-Platonism rather than Stoic philosophy" (18182). To support her particular reading of Barbauld's Stoicism, Clery further cites the example of Tacitus, who has been considered a seminal figure within the tradition of classical republicanism as well as having been identified with Stoicism.
} 
to "injur'd Afric" in the opportunity not only for revenge but also for at least a partial claim to republican motherhood in her resistance to tyranny. In this context, Barbauld perhaps draws inspiration from William Shakespeare's Cleopatra. In Antony and Cleopatra, Cleopatra rejoices in her "noble act" of suicide, allowing her to escape the humiliation of being led in public triumph following her defeat at the hands of Octavian (later Augustus) Caesar. She envisions her act of suicide, in which she applies an asp smuggled past her guards to her breast, in strikingly maternal terms, crying, "Peace, peace! / Dost thou not see my baby at my breast, / That sucks the nurse asleep?" (Shakespeare 5.2.30709). Thus, she challenges those who have regarded her throughout the play as the antithesis of the Roman matron. The clown who delivers her suicide weapon emphasizes the sexual connotations of the snake, repeatedly wishing Cleopatra "joy" of the "worm." Confronted with the sight of the dead queen, Caesar continues to dwell upon her persisting sexual allure, remarking that she looks "[a]s if she would catch another Antony / In her strong toil of grace" (5.2.34546). Yet Shakespeare's Cleopatra effectively shows herself a better Roman than either Antony, who botches his suicide attempt, and Caesar, bent upon the final destruction of the Roman Republic.

Liberty comes together again with sympathy in "To a Great Nation," Barbauld simultaneously celebrating France's achievement of "Freedom" and pleading with the revolutionaries to "wash with sad repentant tear / Each deed that clouds ... [their] glory's page" (21-22). The poem concludes with an image of motherly tenderness, as the poet encourages France to "fold in thy relenting arms, / Thy wretched outcasts where they roam" (25-26).

It may well be that Locke and Rousseau provided Barbauld with a point of convergence between the discourses of ancient republicanism and modern commercial society. The citizen-making function of education was something that Locke and Rousseau equally took for granted, the former insisting that a great purpose of education is to render a man "[e]minent and useful to his Country according to his station" (161) and counselling, as part of his plan for education, that boys be encouraged to acquire the necessary hardiness and fortitude to enable them to sacrifice "their lives for their Country" (199). ${ }^{21}$ In Émile, ou de l'éducation (1762), Rousseau insists that it was the women who had made the ancient Spartans, Romans, and Germans glorious in raising sons to be patriots. Unlike many male contemporaries, he actually approves the Spartan mother who gives thanks to the gods for victory in a battle in which all five of her sons are

21. Many regard the republican conception of patriotism as distinctive in its emphasis upon the need to sacrifice personal to public interest, but the prioritization of public interest is precisely what Locke here highlights. 
killed. Mary Hilton argues that Rousseau generally saw the wife and mother as providing "a source of moral strength for the male citizen" by learning "to suppress her weaker sexual self," a "theme" that "was a powerful one for contemporary women" (37). In related terms, Philip Hicks notes that Rousseau, "while pointing out the physical and intellectual inferiority of women, also highlighted their ability to nurture public virtue within the home" (47).

As an educational theorist, Barbauld does not appear to have seen any conflict between Lockean and classical republican thought. In her 1798 essay "What is Education?" she advises parents to read Xenophon and Macaulay alongside Locke. Among ancient classical writers, Xenophon famously promoted a statesponsored educational system with a distinctly republican emphasis on public service. McCarthy briefly speculates that Barbauld patterned her Lessons on Xenophon's Cyropedia or Cyropaedia in aiming to create "a better kind of citizen" (Voice 198-99). Catharine Macaulay Graham (née Sawbridge), like Barbauld herself, sat for portraits representing her as a Roman matron. In her educational writings, she holds up citizens of the ancient republics as patriotic models and recommends the reading of "classical republican" writers such as Cicero, though she chastises him and Xenophon for falling short of their own political ideals (Macaulay 200). At least one scholar has speculated that Macaulay chose the name "Hortensia" for the female addressee of Letters on Education (1790) because of its root meaning, positioning Macaulay as cultivator of her friend's mind (Gunther-Canada 48). Yet "Hortensia" is the name of the Roman matron Hicks calls "the most public and brazenly political of all" for speaking out "in the forum, the heart of Roman political life, and on behalf of women" (51).

Notably, historians have increasingly recognized that the political discourse most often associated with Locke and Rousseau, that of natural rights and the social contract, was distinct from but not necessarily at odds with republican discourse. As Philp emphasizes, many scholars have historically assumed a "fundamental incompatibility ... between social contract arguments and the commitment of the republican tradition, yet the traditions often interleave without embarrassment" (466). Michael P. Zuckert explains that much of this perceived incompatibility stems from a confusion over the difference between "political science" and "political philosophy," and that "[m]ost of what is currently discussed as classical republicanism is political thought at the level of political science; most of what is discussed as liberalism is reflection at the level of political philosophy" (165). While Rousseau was more ambivalent toward commerce than many of his contemporaries, both he and Locke have been recognized among the Enlightenment thinkers who encouraged new interest in and theorization of the concept of sympathy. Indeed, Locke was apparently one of the first to make the 
cultivation of sympathy a vital component of education. ${ }^{22}$ Moreover, in the days before a salon culture was properly established in England, he enjoyed a number of important friendships with female intellectuals, most notably Damaris Masham (née Cudworth), whom Peter Laslett calls "the first bluestocking of them all" (536). To a male friend, he enthused that Masham was "so well versed in theological and philosophical studies and of such an original mind that you will not find many men to whom she is not superior in wealth of knowledge and ability to profit by it" (qtd. in Butler 117). A regular participant in the French salons at the height of their renown across Europe, Rousseau notoriously attacked the salonnière as at odds with a woman's duties as wife and mother. Possibly Barbauld seeks to answer him with her portrait of Amanda, who moves effortlessly between her activities as hostess and mother-teacher.

However, there is a further complicating dimension to Barbauld's poetic representations of the maternal. In "Bouts Rimés in Praise of old Maids" (c. 1770; 1828), wives give up "free enjoyments" (3) for "household cares" (3) and face the prospects of both "husband Fickle" (9) and "children cropt by death's untimely Sickle" (10), calling to mind Amanda Vickery's reflections upon the inevitable limitations of eighteenth-century maternal propaganda. As Vickery puts it, "The experience [of motherhood] was too cruel, unpredictable and unremittingly physical to be decently covered by such a sugary wrapping" (94). ${ }^{23}$ Despite the poem's humorous tone, the prospects of married life appear even bleaker given the lack of meaningful alternative, as old maids seek to mask feelings of isolation and irrelevance in a whirlwind of social activity and preoccupation with fashion. A surviving copy of "Bouts Rimés" notably includes a possibly satirical reference to Sarah Scott's A Description of Millennium Hall (1762), which presents a utopian vision of single female life. ${ }^{24}$

Many of Barbauld's other poetic treatments of the maternal are far from straightforwardly celebratory. The poet welcomes the newborn infant of "On the Birth of a Friend's Eldest Son" $(1768 ; 1994)$ with a sobering reference to the "pains" of childbirth and "[j]oy . . . mix'd with trouble" (14). While identified as heir to his "father's virtues" and "mother's charms," baby Joseph remains a "helpless stranger" of as yet indiscernible potential and unpredictable future in this "chequer'd life" (20) of "various fortune" (19).

\footnotetext{
22. See Barker-Benfield 106.

23. The following critics explore related tensions in Barbauld's attitudes towards domestic labor: Messenger, Landry, and Kraft.

24. See McCarthy and Kraft's note in Barbauld, Poems 241.
} 
In "Verses in an ivory Pocket-book," the poet worries that, if his education is not managed properly, Master Turner will grow up badly. While expressing final confidence in the care his parents are taking, she concludes by reminding readers of the limitations of education and of our ultimate reliance upon Providence (points she picks up later in "What is Education?"). Meanwhile, the poet in "To a little invisible Being who is expected soon to become visible" (c. 1795; 1825) expresses serious misgivings about pregnancy (McCarthy speculates that Barbauld might have suffered one or more miscarriages) in the image of the unborn child trapped within a "living tomb" (20), vampirically feeding on the "life" of its "anxious mother" (15) "through many a tedious moon" (24). The image of the vampiric unborn child may also anticipate the responsibilities of the nursing mother and the post-Rousseauian pressure on middle-class women to nurse their own infants. Finally, the widowed matron of Eighteen Hundred and Eleven, who has outlived all her sons, reminds us that even if mothers managed to raise children successfully into adulthood, they could never be secure.

The situation of the widowed matron is all the more poignant given the poem's critical reception, which testifies to the ultimate failure of Barbauld's efforts to legitimize poetic interventions into politics through her invocation of the maternal. In a letter sent to Barbauld in 1769, Joseph Priestley writes:

Mr. [William] Turner of Wakefield, who says he reads your poems not with admiration but astonishment, insists upon my writing to you, to request that a copy of your poem called Corsica may be sent to Mr. Boswell, with permission to publish it for the benefit of those noble islanders. He is confident that it cannot fail greatly to promote their interest now that a subscription is open for them, by raising a generous ardor in the cause of liberty, and admiration of their glorious struggles in its defence. Its being written by a lady, he thinks, will be a circumstance very much in . . . [its] favour. (qtd. in Le Breton 34-35)

The basis of this expectation is not entirely clear. Perhaps Turner and Priestley are simply placing faith in the chivalric impulses of male critics, but Priestley takes occasion in the same letter to compare Barbauld with Tyrtaeus, the ancient Spartan poet credited with inventing the martial elegy, the focus of which is exhortation to brave military service, implying that both he and Turner anticipate a positive reception specifically for Barbauld's appeal to republican motherhood. 
As late as 1792, George Dyer could publicly praise Barbauld in republican language, describing his pleasure at hearing the "sweet enthusiast" Liberty "warble in Laetitia's Song" (36). However, the British counter-revolution clearly deprived republican motherhood of much of its cultural currency. Penny Mahon finds Barbauld already preoccupied with an increasing disjunction between "private" and "public" in Sins of the Government, Sins of the Nation (1793). ${ }^{25}$ Josephine McDonagh reads Eighteen Hundred and Eleven as an expression of Barbauld's resistance to a growing privatization of women's "maternal" and "domestic function," identified as a cause of Britain's decline. ${ }^{26}$ Reviewing the poem anonymously for The Quarterly Review, John Wilson Croker completely discountenances the possibility that women might legitimately speak as patriots, patronizingly remarking, "We had hoped, indeed, that the empire might have been saved without the intervention of a lady-author" (309). He thus deliberately ignores the historical precedent of classical republican motherhood. At the same time, he trivializes the achievement of Barbauld's prose writing for children and, with it, her associated literary reputation and authority. In a move that has been characterized by Myers as a calculated "infantilization of his childhood instructress" ("Of Mice" 265), he denies any "disposition to retaliate on the fair pedagogue of our former life" in "call[ing] her up to correct her exercise" (Croker 309). Alternating between faint praise and insult, he dismisses Barbauld's famous prose pieces for children as "something better than harmless [and] of some utility ... though they display not much of either taste or talents" (313). McCarthy identifies Croker as the first reviewer who "linked Barbauld's sex with her writings for children and used that combination of gender and genre to deny her right to poetry and politics" ("Introduction" 12). Yet other reviewers similarly targeted her prose writing for children as part of their efforts to discredit Barbauld as a political poet. For example, the reviewer for The Universal Magazine alleges that her prose pieces for children all suffer from "the same cold regularity, the same frigid observance of what is right without any thing that is very good" (Review 217). ${ }^{27}$ Perhaps tacitly admitting the combined authority Barbauld had once achieved as Enlightenment mother-teacher and eighteenth-century republican mother, Croker ultimately attempts to sever her associations with the maternal altogether. As William Keach observes, the rather odd designation of the widowed poet as a "fatidical spinster" (Croker 309) places her "outside both the 'conjugal family' and the 'public sphere' into which she has intruded" (571).

\footnotetext{
25. See 23-38.

26. See 62-77.

27. For other issues related to the reception of Eighteen Hundred and Eleven see Ross, Favretti, Gottlieb, Clery (who identifies an element of anti-Stoicism in contemporary responses), and Murphy.
} 
All too clearly, at this historical juncture, Barbauld's prose writing for children had become part of the threat for those who saw her overstepping gender boundaries. It had not been so before. Samuel Johnson once famously regretted that Barbauld was wasting her talents in teaching and writing for infants, and James Barry lamented her career shift as an apparent renunciation of the public and patriotic aims of such poems as "Corsica." 28 The revolutionary debates produced the first hints of concern about Barbauld exploiting the authority that she had gained as a mother-teacher in order to speak publicly about politics. The political illustration Don Dismallo Running the Literary Gantlet [sic] (1790) features Barbauld about to give Edmund Burke a whipping, exclaiming, "[T]he most incorrigible Urchin in my School never felt from my hands what this Assassin of Liberty shall now feel!" However, in his notorious anti-feminist satire, The Unsex'd Females (1798), first published anonymously, Richard Polwhele qualifies his condemnation of Barbauld's political pamphleteering with a footnote that recalls her as one of his favourites when he "first ... 'lisp'd in numbers"' (21n).

Closer to Croker than Polwhele are the male Romantics. As Deirdre Coleman has established, Coleridge contributed directly towards "the increasingly misogynist assessment of ... [Barbauld] as an unimaginative, didactic, schoolmarmish pedagogue who wrote lessons and verses for children" (148). ${ }^{29}$ At the same time, Coleridge and Southey privately mocked Barbauld with a masculine sounding nickname, "Mistress Bare and Bald." ${ }^{30}$ Meanwhile, Charles Lamb could complain in one breath that Barbauld was overly didactic and in another that she was "unfeminine." 31 While McCarthy and others have cited personal grievances that Lamb, Southey, and Coleridge had against Barbauld, few find these an adequate explanation alone for their treatment of her. ${ }^{32}$ Instead, this treatment reveals resentment of a woman who had assumed maternal authority over them and who had achieved enviable literary success as a maternal educator. ${ }^{33}$ Surely, William Hazlitt had no personal grievance to motivate him when he leaped onto the

\footnotetext{
28. See Boswell 662-63 and Barry 80, 81-82.

29. Myers blames the negative male Romantic response to Barbauld upon the influence of Rousseau's misogyny (256).

30. See Coleridge, Notebooks 3: 3965.

31. Charles Lamb's notorious attack against Barbauld's didacticism occurs in a letter to Coleridge (see Lamb 1: 138-39). It is Coleridge who records Lamb's characterization of Barbauld as "unfeminine" (Coleridge, Letters 1: 218). For more scholarship on Lamb and Barbauld, consult Barnett, Clarke, and Mandell.

32. For more on this point, see McCarthy, Voice 448-49.

33. In her analysis of the contemporary response to Eighteen Hundred and Eleven, Newlyn speculates that readers were "most offended" by the degree of "authority" with which the poet speaks (168).
} 
bandwagon and belittled Barbauld's literary reputation, and, as far as we can tell, Rogers retained all his old affection for Barbauld when he quipped, "How strange it is that while we men are modestly content to amuse by our writings, women must be didactic" (qtd. in Robinson 436). ${ }^{34}$

Later, responding to the backlash against Eighteen Hundred and Eleven, Lucy Aikin made some effort to defend her aunt. Her insistence that the poem was "dictated by the heart of a true patriot, a heart which feared because it fondly loved" (1: li) arguably attempts to uphold the poem's appeal to a modified form of republican motherhood. Yet her defence remains somewhat tentative, and scholars have accused her of doing her own damage to Barbauld's reputation by deliberately seeking to represent her aunt as an uncontroversial "motherly teacher in person and texts" (Robbins, "Re-making" 159). Catering perhaps to the reading public's preference for women's writing that did not seem to risk the violation of prescribed categories of gender activity, she has been seen as devoting disproportionate attention to Barbauld's prose writings for children, which continued to be widely circulated on both sides of the Atlantic well into the nineteenth century. Moreover, the very success of these writings, when such works as "Corsica" and Eighteen Hundred and Eleven were being forgotten, has itself been seen as damaging Barbauld's long-term reputation. Another nineteenth-century memoirist, Grace A. Ellis, admired Barbauld's prose writings for children but feared that their popularity was overshadowing the rest of her oeuvre and preventing a full appreciation of her "genius" (x). A number of critics since have confirmed the legitimacy of Ellis's fears. ${ }^{35}$ Part of the persisting negative perception of Barbauld evidently had to do with a post-Romantic reading of the history of children's literature premised upon a misleading (and gendered) dichotomization of "educators into the merely instructive and the mentally emancipatory" (Myers, "Of Mice" 266). Recent challenges to this perspective have enabled a positive reassessment of Barbauld's prose writing for children and appreciation of the ways in which they serve to foster critical and even oppositional thinking. ${ }^{36}$

\footnotetext{
34. For more on Hazlitt and Barbauld, consult Keach, "Barbauld, Romanticism, and the Survival of Dissent."

35. See, for example, McCarthy, "A 'High-Minded Christian Lady," and Vargo. Going a step farther, Battles regards Barbauld's career as a children's writer, despite gaining her some "agency," ultimately as "a trap" that "[framed] her public authorial persona in such a way that the shift she made back to an authoritative masculinized voice in Eighteen Hundred and Eleven created a sharp dissonance for readers" and sabotaged her career as a poet (145). Battles additionally posits that Barbauld finally gave up the role of mother-teacher because it allowed only for gradual change through indirect influence, and she had become impatient.

36. See, for example, McCarthy, "Performance, Pedagogy, and Politics," Levy, "Radical Education," and Helms.
} 
If this body of writing has finally regained the respect it deserves, however, there remain, it seems, many important connections to think through between it and the rest of Barbauld's oeuvre. Exploring the relationship between the Enlightenment mother-teacher in Barbauld's prose writings for children and the complex maternal ideal that emerges from her poetry constitutes but one such exercise. A better understanding of Barbauld's maternal ideal has implications, in turn, for thinking about the writing of other women during the period, particularly those who, like Barbauld, cultivated the image of the mother-teacher; those who, across the political spectrum, shared a sense of maternal vocation sanctioning activity beyond the domestic sphere; and those who faced the same critical hostility and posthumous neglect. Evidently, the maternal and gender itself have limitations as categories for analysis. Michelle Levy, for one, has made a point of deemphasizing the maternal as a relevant category of analysis for Barbauld, insisting that the latter's "politics must be distinguished from the brand of maternal or matriarchal feminism ... described by scholars like Anne Mellor and Eve Bannet" (Family 29). Certainly, one might debate the relative merits of the label "maternal or matriarchal feminism" as applied to Barbauld. Yet there are challenges in attempting to separate a bid for authority based on family identity from one based on maternal prerogative, especially since motherhood was a principal and defining role for women within the family and for Barbauld within her own family. In general, it seems that the topic of motherhood continues to present rich scope for scholars in the field of eighteenth-century studies and beyond. We have likely not yet exhausted this topic, as scholars continue to think about motherhood historically and changing perceptions of it and to evaluate the implications, both positive and negative for women, before, during, and after this era. $^{37}$

\footnotetext{
37. Some, like Vickery, still question whether the eighteenth-century maternal ideal represented a major break with the past. Among those who assume a break, some, like Myers, are positive; others are starkly negative, including Kowaleski-Wallace, Perry, and Bowers.
} 


\section{Works Cited}

Aikin, John. An Address to the Dissidents of England on their Late Defeat. London, J. Johnson, 1790.

- The Spirit of the Constitution and that of the Church of England, compared. London, J. Johnson, 1790.

Aikin, Lucy, editor. Works of Anna Laetitia Barbauld, With a Memoir by Lucy Aikin. London, Longman, Hurst, Rees, Orme, Brown, and Green, 1825. 2 vols.

Barbauld, Anna Letitia. Lessons for Children, from Three to Four Years Old. 1779. London, J. Johnson, 1784.

—. Lessons for Children, of Three Years Old. Part I. 1778. London, J. Johnson, 1788.

—. Lessons for Children, of Three Years Old. Part II. 1779. London, J. Johnson, 1788.

—. Lessons for Children, from Two to Three Years Old. 1778. London, J. Johnson, 1787.

_. Poems of Anna Letitia Barbauld, edited by William McCarthy and Elizabeth Kraft, Athens, University of Georgia Press, 1994.

- Selected Poetry and Prose, edited by William McCarthy and Elizabeth Kraft, Broadview Press, 2002.

Barker-Benfield, G. J. The Culture of Sensibility: Sex and Society in EighteenthCentury Britain. University of Chicago Press, 1992.

Barnett, George L. '“The Cursed Barbauld Crew,' or Charles Lamb and Children's Literature." Charles Lamb Bulletin, vol. 25, 1979, pp. 1-18.

Barry, James. An Account of a Series of Pictures, in the Great Room of the Society of Arts, Manufactures, and Commerce, of the Adelphi. London, William Adlard, 1783. 
Battles, Kelly. “Anna Barbauld's Authorial Self-Fashioning: From 'Fair Pedagogue' to 'Fatidical Spinster."' Studies in Eighteenth-Century Culture, vol. 44, 2015, pp. 143-62.

Boswell, James. The Life of Samuel Johnson. Edited by R. W. Chapman, Oxford UP, 1998.

Bowers, Toni. The Politics of Motherhood: British Writing and Culture, 1680 1760. Cambridge UP, 1996.

Bowles, John. Remarks on Modern Female Manners. London, F. and C. Rivington, 1802.

Butler, Melissa A. "Early Liberal Roots of Feminism: John Locke's Attack on Patriarchy." Feminist Interpretations of John Locke, edited by Nancy J. Hirschmann and Kirstie M. McClure, Pennsylvania State UP, 2007, pp. 91-121.

Clarke, Norma. "The Cursed Barbauld Crew': Women Writers and Writing for Children in the Late Eighteenth Century." Opening the Nursery Door: Reading Writing and Childhood 1600-1900, edited by Mary Hilton, Morag Styles, and Victor Watson, Routledge, 1997, pp. 91-103.

Clery, E. J. "Stoic Patriotism in Barbauld's Political Poems." Anna Letitia Barbauld: New Perspectives, edited by William McCarthy and Olivia Murphy, Bucknell University Press, 2014, pp. 173-94.

Coleman, Deirdre. "The Unitarian Rationalist and the 'Winged Spider': Anna Letitia Barbauld and Samuel Taylor Coleridge." Imperfect Apprehensions: Essays in English Literature in Honour of G. A. Wilkes, edited by Geoffrey Little, Challis, 1996, pp. 148-63.

Coleridge, Samuel Taylor. Letters, Conversations, and Recollections of S. T. Coleridge. London, Edward Moxon, 1836. 2 vols.

—. The Notebooks of Samuel Taylor Coleridge, edited by Kathleen Coburn, Pantheon, 1957-90. 5 vols.

Cox, Philip. Gender, Genre and the Romantic Poets. Manchester UP, 1996.

Crabb Robinson, Henry. On Books and Their Writers. vol. 1. Edited by Edith J. Morley, J. M. Dent, 1938. 3 vols. 
[Croker, John Wilson.] Article VI. Review of Eighteen Hundred and Eleven. Quarterly Review, vol. 7, no. 14, June 1812, pp. 309-13.

Darton, F. J. Harvey. Children's Books in England: Five Centuries of Social Life. Cambridge UP, 1982.

Davies, Kate. "A Moral Purchase: Femininity, Commerce and Abolition, 17881792." Women, Writing and the Public Sphere, 1700-1830, edited by Elizabeth Eger, Charlotte Grant, Clíona Ó Gallchoir, and Penny Warburton, Cambridge U P, 2001, pp. 133-62.

Don Dismallo Running the Literary Gantlet. London, William Holland, 1790. British Museum, https://www.britishmuseum.org/collection/object/P_1868-0808-5976.

Dyer, George. Poems. London, J. Johnson, 1792.

Ellis, Grace A., editor. A Memoir of Mrs. Anna Laetitia Barbauld with many of her Letters. vol. 1. Boston, James R. Osgood, 1874. 2 vols.

Favretti, Maggie. "The Politics of Vision: Anna Barbauld's 'Eighteen Hundred and Eleven." Women's Poetry in the Enlightenment: The Making of a Canon, 1730-1820, edited by Isobel Armstrong and Virginia Blain, St. Martin's Press, 1999, pp. 99-110.

Goldstone, Bette P. Lessons to be Learned: A Study of Eighteenth-Century English Didactic Children's Literature, Peter Lang, 1984.

Gottlieb, Evan. "Fighting Words: Representing the Napoleonic Wars in the Poetry of Hemans and Barbauld." European Romantic Review, vol. 20, no. 3, 2009, pp. 327-43.

Guest, Harriet. Small Change: Women, Learning, Patriotism, 1750-1810. University of Chicago Press, 2000.

Gunther-Canada, Wendy. "Cultivating Virtue: Catharine Macaulay and Mary Wollstonecraft on Civic Virtue." Women and Politics, vol. 25, no. 3, 2003, pp. $47-70$.

Helms, Whitney. "Appropriating Maternal Authority and Politicizing the Domestic: Anna Barbauld and Children's Literature." Eighteenth-Century Women, vol. 6, 2011, pp. 209-27. 
Hicks, Philip. "The Roman Matron in Britain: Female Political Influence and Republican Response, ca. 1750-1800.” The Journal of Modern History, vol. 77, no. 1, March 2005, pp. 35-69.

Hilton, Mary. Women and the Shaping of the Nation's Young: Education and Public Doctrine in Britain, 1750-1850. Ashgate, 2007.

Home, Henry, Lord Kames. Sketches of the History of Man. vol. 1. Edinburgh, W. Creech, 1774. 2 vols.

Hume, David. "Of Refinement in the Arts." Essays: Moral, Political, and Literary, by Hume. Edited by Eugene F. Miller, 2nd. ed., Liberty Fund, 1987, pp. 268-80.

Keach, William. "Barbauld, Romanticism, and the Survival of Dissent." Essays and Studies, vol. 51, 1998, pp. 44-61.

—. "A Regency Prophecy and the End of Anna Laetitia Barbauld's Career." Studies in Romanticism, vol. 33, no. 4, 1994, pp. 569-77.

Kowaleski-Wallace, Elizabeth. Their Fathers' Daughters: Hannah More, Maria Edgeworth, and Patriarchal Complicity. Oxford UP, 1991.

Kraft, Elizabeth. “Anna Letitia Barbauld's 'Washing-Day' and the Montgolfier Balloon.” Literature and History, vol. 4, no. 2, 1995, pp. 25-41.

Lamb, Charles. The Complete Correspondence and Works, edited by Thomas Purnell, London, E. Moxon, 1870. 4 vols.

Landry, Donna. The Muses of Resistance: Laboring-Class Women's Poetry in Britain, 1739-1796. Cambridge UP, 1990.

Laslett, Peter. "Masham of Otes: The Rise and Fall of an English Family." History Today, vol. 3, no. 8, August 1953, pp. 535-43.

Le Breton, Anna Letitia. Memoir of Mrs. Barbauld, including Letters and Notices of her Family and Friends. London, G. Bell, 1874.

Levy, Michelle. Family Authorship and Romantic Print Culture. Palgrave Macmillan, 2008.

- "The Radical Education of Evenings at Home." Eighteenth-Century Fiction, vol. 19, no. 1-2, 2006-07, pp. 123-50. 
Locke, John. Some Thoughts concerning Education, edited by John W. and Jean S. Yolton, Clarendon Press, 1990.

Macaulay, Catharine. Letters on Education with Observations on Religious and Metaphysical Subjects. London, C. Dilly, 1790.

Mahon, Penny. "In Sermon and Story: Contrasting Anti-war Rhetoric in the Work of Anna Barbauld and Amelia Opie." Women's Writing, vol. 7, no. 1, 2000, pp. 23-38.

Mandell, Laura. Misogynous Economies: The Business of Literature in Eighteenth-Century Britain. University Press of Kentucky, 1999.

McCarthy, William. Anna Letitia Barbauld: Voice of Enlightenment. Baltimore, The Johns Hopkins U P, 2008.

— . "The Celebrated Academy at Palgrave: A Documentary History of Anna Letitia Barbauld's School.” Age of Johnson, vol. 8, 1997, pp. 279-393.

—_. "A 'High-Minded Christian Lady': The Posthumous Reception of Anna Letitia Barbauld." Romanticism and Women Poets: Opening the Doors of Reception, edited by Harriet Kramer Linkin and Stephen C. Behrendt, University Press of Kentucky, 1999, pp. 165-191.

—_. "Introduction: Anna Letitia Barbauld Today." Anna Letitia Barbauld: New Perspectives, edited by William McCarthy and Olivia Murphy, Bucknell University Press, 2014, pp. 1-21.

—_. "Performance, Pedagogy, and Politics: Mrs. Thrale, Mrs. Barbauld, Monsieur Itard." Childhood and Children's Books in Early Modern Europe, 1550-1800, edited by Andrea Immel and Michael Witmore, Routledge, 2006, pp. 261-76.

McDonagh, Josephine. "Barbauld's Domestic Economy.” Essays and Studies, vol. 51, 1998, pp. 62-77.

McGillis, Rod. "That Great Writer in the English Language.” Children's Literature Association Quarterly, vol. 13, no. 4, Winter 1988, pp. 162-63.

MacLachlan, Herbert. English Education under the Test Acts: Being the History of the Non-Conformist Academies, 1662-1820. Manchester UP, 1931. 
Messenger, Ann. His and Hers: Essays in Restoration and Eighteenth-Century Literature. University Press of Kentucky, 1986.

Murphy, Olivia. "Riddling Sibyl, Uncanny Cassandra: Barbauld's Recent Critical Reception." Anna Letitia Barbauld: New Perspectives, edited by William McCarthy and Olivia Murphy, Bucknell University Press, 2014, pp. 27797.

Myers, Mitzi. "Impeccable Governesses, Rational Dames, and Moral Mothers: Mary Wollstonecraft and the Female Tradition in Georgian Children's Books." Children's Literature, vol. 14, 1986, pp. 31-59.

_ . "Of Mice and Mothers: Mrs. Barbauld's 'New Walk' and Gendered Codes in Children's Literature." Feminine Principles and Women's Experience in American Composition and Rhetoric, edited by Louise Wetherbee Phelps and Janet Emig, University of Pittsburgh Press, 1995, pp. 225-88.

Newlyn, Lucy. Reading, Writing, and Romanticism: The Anxiety of Reception. Oxford UP, 2000.

Perry, Ruth. "Colonizing the Breast: Sexuality and Maternity in EighteenthCentury England.” Eighteenth-Century Life, vol. 16, no. 1, 1992, pp. 185213.

Philp, Mark. "Enlightenment, Republicanism, and Radicalism." The Enlightenment World, edited by Martin Fitzpatrick, Peter Jones, Christa Knellwolf, and Iain McCalman, Routledge, 2004, pp. 457-72.

Pickering, Samuel F., Jr. John Locke and Children's Books in Eighteenth Century England. University of Tennessee Press, 1981.

Pocock, J. G. A. Virtue, Commerce, and History. Cambridge UP, 1985.

[Polwhele, Richard]. The Unsex'd Females. London, Cadell and Davies, 1798.

Ready, Kathryn. "Damaris Cudworth Masham, Catharine Trotter Cockburn, and the Feminist Legacy of Locke's Theory of Personal Identity." EighteenthCentury Studies, vol. 35, no. 4, 2002, pp. 563-76.

Review of Eighteen Hundred and Eleven. Universal Magazine, new series, vol. 17, January-July 1812, pp. 217-18. 
Robbins, Sarah R. "Lessons for Children and Teaching Mothers: Mrs. Barbauld's Primer for the Textual Construction of Middle-Class Domestic Pedagogy." The Lion and the Unicorn, vol. 17, no. 2, December 1993, pp. 135-51.

—_. "Re-making Barbauld's Primers: A Case Study in the Americanization of British Literary Pedagogy." Children's Literature Association, vol. 21, no. 4, 1996, pp. 158-69.

Ross, Marlon. "Configurations of Feminine Reform: The Woman Writer and the Tradition of Dissent." Re-Visioning Romanticism: British Women Writers 1776-1837, edited by Carol Shiner Wilson and Joel Haefner, Philadelphia, University of Pennsylvania Press, 1994, pp. 91-110.

Shakespeare, William. Antony and Cleopatra. Edited by David Bevington, Cambridge, Cambridge University Press, 2005.

Stuart, Gilbert. A View of Society in Europe, in its Progress from Rudeness to Refinement. Edinburgh, John Bell and J. Murray, 1778.

Vallone, Lynne. “'A Humble Spirit Under Correction': Tracts, Hymns, and the Ideology of Evangelical Fiction for Children, 1780-1820." The Lion and the Unicorn, vol. 15, no. 2, December 1991, pp. 72-95.

Vargo, Lisa. "A Finer Tone: Victorian Lives of Mrs. Barbauld and Mrs. Shelley." Romantic Echoes in the Victorian Era, edited by Andrew Radford and Mark Sandy, Aldershot, Ashgate, 2008, pp. 15-26.

Vickery, Amanda. The Gentleman's Daughter: Women's Lives in Georgian England. New Haven and London, Yale University Press, 1998.

Wharton, Joanna. "'The Things Themselves': Sensible Images in Lessons for Children and Hymns in Prose." In Anna Letitia Barbauld: New Perspectives, edited by William McCarthy and Olivia Murphy, Lewisburg, Bucknell University Press, 2014, pp. 107-26.

Wootton, David. "The True Origins of Republicanism: The Disciples of Baron and the Counter-example of Venturi." Il repubblicanesimo moderno: L'idea di repubblica nella riflessione storica di Franco Venturi, edited by Manuela Albertone, Naples, Bibliopolis, 2006, pp. 271-304.

Zuckert, Michael P. Natural Rights and the New Republicanism. Princeton, Princeton University Press, 1998. 
Ready: Anna Letitia Barbauld and the Eighteenth-Century Maternal Ideal 